\title{
Carrying capacity assessment in tourism: the case of the Dodecanese archipelago
}

\author{
B. S. Tselentis ${ }^{1}$, D. G. Prokopiou ${ }^{1}$, M. Toanoglou ${ }^{2}$ \\ \& D. Bousbouras ${ }^{3}$ \\ ${ }^{I}$ Department of Maritime Studies, University of Piraeus, Greece \\ ${ }^{2}$ University of Surrey, England \\ ${ }^{3}$ Hellenic Ornithological Society, Greece
}

\begin{abstract}
Greece depends heavily on the tourist trade, as tourism is the main economic activity. Carrying capacity assessment has become an indispensable tool for formulating policy and strategies in the tourist industry worldwide. The Dodecanese archipelago has 19 islands; mainly concentrated over than 250.000 beds. The tourist product is a blend of ecological, social and economic sub-systems, operable in the area of interest. For the Greek Islands, environment, both natural and man made, plays a leading role in the sustainable development of the industry. It is the purpose of this paper to apply the principles of carrying capacity assessment to the Dodecanese islands, differing in their tourist development, in an effort to highlight the importance of such a tool in developing long-term sustainable policies for such communities.
\end{abstract}

\section{Introduction}

The World Tourism Organisation (WTO) proposes the following definition of carrying capacity: "The maximum number of people that may visit a tourist destination at the same time, without causing destruction to the physical, economic, socio-cultural environment and an unacceptable decrease in the quality of visitors' satisfaction." [1].

Today, controlling tourist growth has become a central policy issue for the tourist trade [2], and it is noteworthy that carrying capacity assessment has 
become an important tool for facilitating planning and developing policy in the industry [3]. The Dodecanese islands have a concentration of over 2 million tourist arrivals per year.

Relevant carrying capacity indicators have been developed and categorised into three groups: 1. physical-ecological, 2. infrastructural and 3. Sociologicalpsychological [4]. It is highly topical to develop and integrate such indicators [5] into the planning process of the Greek tourist business.

\section{Basic population characteristics figures for Dodecanese}

Table 1: Population in the Dodecanese: Islands with a population greater than 50 inhabitants.

\begin{tabular}{|c|c|c|c|c|}
\hline \multicolumn{5}{|c|}{ POPULATION CHARACTERISTICS (2001) } \\
\hline Island & Population & $\begin{array}{l}\text { Area } \\
\left(\mathrm{km}^{2}\right)\end{array}$ & $\begin{array}{l}\text { Density } \\
\text { inhabitants } \\
/ \mathrm{km}^{2}\end{array}$ & Municipality status \\
\hline AGATHONISI & 158 & 13,5 & 11,70 & MUNICIPALITY OF AGATHONISSI \\
\hline ARKI & 54 & 6,7 & 8,0 & MUNICIPALITY OF PATMOS \\
\hline ASTYPALAIA & 1.238 & 96,85 & 12,7 & MUNICIPALITYY OF ASTIPALAIA \\
\hline FARMAKONISI & 54 & 3,9 & 13,8 & MUNICIPALITY OF LEROS \\
\hline HALKI & 313 & 28,12 & 11,13 & MUNICIPALITY OF HALKI \\
\hline LEROS & 8.133 & 52,95 & 153,60 & MUNICIPALITY OF LEROS \\
\hline LIPSI & 600 & 15,97 & 37,57 & MUNICIPALITY OF LIPSI \\
\hline KALYMNOS & 13.257 & 110,8 & 148,38 & MUNICIPALITY OF KALYMNOS \\
\hline KARPATHOS & 5.908 & 301,17 & 19,62 & $\begin{array}{l}\text { MUNICIPALITY } \text { OF } \\
\text { MUNICIPALITY OF OLYMPUS }\end{array}$ \\
\hline KASOS & 990 & 65,67 & 15.10 & MUNICIPALITY OF KASOS \\
\hline KOS & 30.947 & 290,2 & 106,64 & $\begin{array}{l}\text { MUNICIPALITIES OF KOS, DIKAIOS, } \\
\text { AND HERACLEIDES }\end{array}$ \\
\hline MEGISTI & 430 & 9,12 & 47,15 & MUNICIPALITY OF KASTELORIZO \\
\hline NISYROS & 948 & 41,4 & 22,90 & MUNICIPALITY OF NISIROS \\
\hline PATMOS & 2990 & 34,05 & 87,81 & MUNICIPALITY OF PATMOS \\
\hline PSERIMOS & 130 & 20 & 6.50 & MUNICIPALITY OF KALYMNOS \\
\hline RHODES & 117.007 & $1.398,07$ & 83,65 & $\begin{array}{l}10 \text { MUNICIPALITIES: ARHAGELOS, } \\
\text { ATTAVIROS, AFANDOU, IALYSOS, } \\
\text { KALLITHEA, KAMIROS, LINDOS, SOUTH } \\
\text { RHODES, PETALOUDES, RHODES TOWN }\end{array}$ \\
\hline SIMI & 2.606 & 58,1 & 44,85 & MUNICIPALITY OF SIMI \\
\hline TELENDOS & 54 & & & MUNICIPALITY OF KALYMNOS \\
\hline TILOS & 533 & 62,82 & 8,48 & MUNICIPALITY OF TILOS \\
\hline
\end{tabular}




\section{Tourist indicators}

\subsection{Tourist development}

Tourist development in Kos started in the early '70s and that in Rhodes started in the 60's. On the other hand, tourist development in Kalymnos, Patmos and Karpathos started in 1989. All development data are presented in table 5.

Table 2: Bed capacity in the Dodecanese related to area and local population.

\begin{tabular}{|c|c|c|c|c|c|c|}
\hline \multicolumn{7}{|c|}{$\begin{array}{l}\text { BED CAPACITY IN DODECANESE (2006) } \\
{ }^{6} \text { Islands with population over than } 50 \text { inhabitants }\end{array}$} \\
\hline & Hotels & $\begin{array}{c}\text { Hotel's } \\
\text { beds }\end{array}$ & $\begin{array}{c}\text { Other } \\
\text { hospitality } \\
\text { enterprises }\end{array}$ & $\begin{array}{c}\text { Beds in } \\
\text { hospitality } \\
\text { enterprises }\end{array}$ & $\begin{array}{l}\text { Total } \\
\text { beds }\end{array}$ & $\begin{array}{l}\text { Density } \\
\text { beds/ } \\
\mathrm{km}^{2}\end{array}$ \\
\hline AGATHONISI & - & - & 3 & 34 & 34 & 2,52 \\
\hline ARKI & - & - & $?$ & 60 & 60 & \\
\hline ASTYPALAIA & 8 & 270 & 91 & 1.073 & 1343 & 13,87 \\
\hline HALKI & 5 & 89 & 38 & 192 & 281 & 9,99 \\
\hline LEROS & 26 & 1.149 & 60 & 846 & 1.995 & 37.68 \\
\hline LIPSI & 2 & 75 & 22 & 234 & 309 & 19,35 \\
\hline KALYMNOS & 44 & 1918 & 102 & 1.216 & 3.134 & 28.29 \\
\hline KARPATHOS & 99 & 4.547 & 93 & 1.323 & 5.870 & 19,49 \\
\hline KASOS & 2 & 27 & 5 & 60 & 87 & 1,33 \\
\hline KOS & 371 & 38.947 & 472 & 10.436 & 49.283 & 169,82 \\
\hline MEGISTI & 3 & 73 & 18 & 200 & 273 & 29,93 \\
\hline NISYROS & 5 & 233 & 10 & 150 & 383 & 9,25 \\
\hline PATMOS & 43 & 1826 & 107 & 1.091 & 2917 & 84.55 \\
\hline PSERIMOS & - & - & $?$ & 24 & 24 & 1,20 \\
\hline RHODES & 511 & 73.420 & 906 & 15.378 & 88.798 & 63,51 \\
\hline SYMI & 13 & 481 & 84 & 569 & 1.050 & 18,07 \\
\hline TELENDOS & 1 & 39 & $?$ & 56 & 95 & \\
\hline TILOS & 5 & 234 & 29 & 419 & 653 & 10,39 \\
\hline
\end{tabular}

Table 3: $\quad$ Closed hotels in the Dodecanese.

\begin{tabular}{|l|l|}
\hline \multicolumn{2}{|c|}{ CLOSED HOTELS IN DODECANESE [7] } \\
\hline ASTYPALAIA & 1 \\
\hline LEROS & 5 \\
\hline KALYMNOS & 9 \\
\hline KOS & 20 \\
\hline PATMOS & 3 \\
\hline RHODES & 76 \\
\hline SYMI & 1 \\
\hline
\end{tabular}


Table 4: $\quad$ Airports and ports in the Dodecanese.

\begin{tabular}{|l|l|l|l|l|l|}
\hline \multicolumn{6}{|c|}{ AIRPORTS AND PORTS IN DODECANESE } \\
\hline & $\begin{array}{l}\text { International } \\
\text { airports }\end{array}$ & National airports & Ports & $\begin{array}{l}\text { Organized } \\
\text { marinas }\end{array}$ & $\begin{array}{l}\text { Shelters for fishing } \\
\text { boats and little ports }\end{array}$ \\
\hline AGATHONISI & - & - & 1 & - & - \\
\hline ARKI & - & - & 1 & - & - \\
\hline ASTYPALAIA & - & 1 & 2 & - & 1 \\
\hline FARMAKONISI & - & - & - & - & 1 \\
\hline HALKI & - & - & 1 & - & - \\
\hline LEROS & - & - & - & - & - \\
\hline LIPSI & - & - & 1 & - & 1 \\
\hline KALYMNOS & - & 1 & 3 & - & 7 \\
\hline
\end{tabular}

Table 5: Bed capacity history in the Dodecanese: Islands with a population greater than 50 inhabitants.

\begin{tabular}{|c|c|c|c|c|c|c|c|c|c|}
\hline \multicolumn{10}{|c|}{ BED CAPACITY HISTORY 1989-2006 } \\
\hline & \multicolumn{3}{|c|}{ Hotel's beds } & \multicolumn{3}{|c|}{$\begin{array}{c}\text { Beds in other } \\
\text { hospitality enterprises }\end{array}$} & \multicolumn{3}{|c|}{$\begin{array}{l}\text { Total } \\
\text { beds }\end{array}$} \\
\hline & $\begin{array}{c}1989 \\
{[8]}\end{array}$ & 1999 & 2006 & 1989 & 1999 & 2006 & 1989 & 1999 & 2006 \\
\hline AGATHONISI & 0 & 0 & 0 & 0 & 0 & 34 & 0 & 0 & 34 \\
\hline ARKI & 0 & 0 & & 0 & 0 & & 0 & 0 & \\
\hline ASTYPALAIA & 128 & 126 & 270 & 326 & 621 & 1.073 & 454 & 747 & 1343 \\
\hline HALKI & - & 88 & 89 & 85 & 141 & 192 & 85 & 229 & 281 \\
\hline LEROS & 541 & 1.187 & 1.149 & 330 & 766 & 846 & 871 & 1.953 & 1.995 \\
\hline LIPSI & 28 & 82 & 75 & 0 & 107 & 234 & 28 & 189 & 309 \\
\hline KALYMNOS & 1.172 & 1.928 & 1918 & 594 & 1.928 & 1.216 & 1.766 & 3.856 & 3.134 \\
\hline KARPATHOS & 603 & 3.823 & 4.547 & 427 & 977 & 1.323 & 1.030 & 4.800 & 5.870 \\
\hline KASOS & 32 & 32 & 27 & 8 & 34 & 60 & 40 & 66 & 87 \\
\hline $\mathrm{KOS}$ & 16.227 & 31.272 & 38.947 & 7.760 & 9.480 & 10.436 & 23.987 & 40.752 & 49.283 \\
\hline MEGISTI & 32 & 32 & 73 & 0 & 176 & 200 & 32 & 208 & 273 \\
\hline NISYROS & 85 & 254 & 233 & 0 & 138 & 150 & 85 & 392 & 383 \\
\hline PATMOS & 1.280 & 1.799 & 1826 & 185 & 776 & 1.091 & 1.465 & 2.575 & 2917 \\
\hline PSERIMOS & 0 & 0 & 0 & - & $\begin{array}{c}\text { 1993: } \\
37\end{array}$ & 24 & 0 & $?$ & 24 \\
\hline RHODES & 45.059 & 65.500 & 73.420 & 13.127 & 13.489 & 15.378 & 58.206 & 76.989 & 88.798 \\
\hline SYMI & 220 & 473 & 481 & 113 & 493 & 569 & 333 & 996 & 1.050 \\
\hline TELENDOS & 0 & 96 & 39 & 0 & 0 & 56 & 0 & 96 & 95 \\
\hline TILOS & 75 & 0 & 234 & 17 & 141 & 419 & 75 & 141 & 653 \\
\hline
\end{tabular}

For tables 5, 6, 7 and 8 we have not any data for: Agathonisi, Arki, Astpalaia, Lipsi, Pserimos and Telendos. Economic crises have taken place in tourist enterprises; a lot of hotels have stopped working (Table 3). As indicated by Table 7, the island of Kos has the most arrivals and overnight stays per 100 
inhabitants compared to the other islands. As indicated by Table 8, total airport arrivals do not compare to hotel arrivals, indicating that other lodgings are operable in the islands, such as non-licensed hotels and rooms to let, as well as camping facilities that are not taken into account in the official statistics.

\subsection{Tourist arrivals, related to local population, during high and low season}

Table 6: Overnight stays.

\begin{tabular}{|l|c|c|}
\hline \multicolumn{3}{|c|}{ OVERNIGHT STAYS IN HOTELS AND OTHER ROOMS IN 2003} \\
\hline & $\begin{array}{c}\text { Low season, overnight stays in } \\
\text { October }\end{array}$ & $\begin{array}{c}\text { High season, } \\
\text { overnight stays in August }\end{array}$ \\
\hline LEROS & 201 & 2.345 \\
\hline KALYMNOS & 944 & 14.599 \\
\hline KARPATHOS & 4.736 & 46.358 \\
\hline KASOS & 12 & 59 \\
\hline KOS & 359.636 & 1.077 .136 \\
\hline MEGISTI & 53 & 288 \\
\hline NISYROS & 529 & 1.883 \\
\hline PATMOS & 991 & 13.613 \\
\hline RHODES & 949.104 & 1.906 .729 \\
\hline SYMI & 2.294 & 1.518 \\
\hline TILOS & 15 & 1.889 \\
\hline
\end{tabular}

Table 7: $\quad$ Tourists related to residents.

\begin{tabular}{|l|c|c|c|c|}
\hline \multicolumn{5}{|c|}{ TOURIST ARRIVALS IN HOTELS PER 100 INHABITANTS IN 2003} \\
\hline & $\begin{array}{l}\text { Low season, } \\
\text { October airport } \\
\text { arrivals per 100 } \\
\text { inhabitants }\end{array}$ & $\begin{array}{l}\text { High season, } \\
\text { August airport } \\
\text { arrivals per 100 } \\
\text { inhabitants }\end{array}$ & $\begin{array}{l}\text { Low season, } \\
\text { overnight stays } \\
\text { per day/ 100 } \\
\text { inhabitants }\end{array}$ & $\begin{array}{l}\text { High season, } \\
\text { overnight stays } \\
\text { per day/ 100 } \\
\text { inhabitants }\end{array}$ \\
\hline ASTYPALAIA & 24,31 & 78.19 & - & - \\
\hline LEROS & 10,11 & 15 & 2.47 & 28,83 \\
\hline KALYMNOS & 1,95 & 118,4 & 0,1 & 1,95 \\
\hline KARPATHOS & 57,74 & 265,25 & 80,16 & 815,88 \\
\hline KASOS & 24,04 & 41,31 & 1,21 & 5,96 \\
\hline KOS & 403,37 & 484,54 & 1.162 .10 & 3480,58 \\
\hline MEGISTI & 71,86 & 187,21 & 12,33 & 66,98 \\
\hline NISYROS & - & - & 55,80 & 198,63 \\
\hline PATMOS & - & - & 33,14 & 455,28 \\
\hline RHODES & 122,67 & 255,34 & 811,15 & $1.629,58$ \\
\hline SYMI & - & - & 88,03 & 58,25 \\
\hline TILOS & - & - & 2,81 & 354,41 \\
\hline
\end{tabular}


Table 8: $\quad$ Comparison of airport arrivals to hotel arrivals.

\begin{tabular}{|c|c|c|c|c|}
\hline \multicolumn{5}{|c|}{$\begin{array}{l}\text { AIRPORT AND HOTEL AND OTHER ACCOMMODATION ENTERPRISES } \\
\text { ARRIVALS IN } 2003^{9}\end{array}$} \\
\hline & $\begin{array}{l}\text { Arrivals in the } \\
\text { airports, } \\
\text { October }\end{array}$ & $\begin{array}{l}\text { Arrivals in the } \\
\text { airports, August }\end{array}$ & $\begin{array}{l}\text { Arrivals in hotels } \\
\text { and other rooms, } \\
\text { October }\end{array}$ & $\begin{array}{lr}\text { Arrivals } & \text { in } \\
\text { hotels and } \\
\text { other rooms, } \\
\text { August }\end{array}$ \\
\hline ASTYPALAIA & 301 & 968 & & \\
\hline LEROS & 822 & 1.221 & 95 & 422 \\
\hline KALYMNOS & - & - & 503 & 2.426 \\
\hline KARPATHOS & 3.234 & 15.130 & 584 & 5.503 \\
\hline KASOS & 238 & 409 & 9 & 32 \\
\hline KOS & 124.832 & 149.952 & 53.000 & 137.000 \\
\hline MEGISTI/KASTELORIZO & 309 & 805 & 17 & 48 \\
\hline NISYROS & - & - & 112 & 302 \\
\hline PATMOS & - & - & 402 & 2.966 \\
\hline RHODES & 143.528 & 298.752 & 117.000 & 256.000 \\
\hline SYMI & - & - & 329 & 1.518 \\
\hline
\end{tabular}

Table 9: $\quad$ Beach impact factor for Rhodes.

\begin{tabular}{|l|c|c|c|c|c|c|c|}
\hline \multicolumn{7}{|c|}{ BEACH IMPACT FACTOR IN DODECANESE } \\
\hline Municipalities & $\begin{array}{c}\text { Beach } \\
\text { length } \\
(\mathrm{m})\end{array}$ & Inhabitants & $\begin{array}{c}\text { Hotel } \\
\text { beds }\end{array}$ & $\begin{array}{c}\text { Rooms } \\
\text { to let } \\
\text { (beds) }\end{array}$ & $\begin{array}{c}\text { Total } \\
\text { beds }\end{array}$ & $\begin{array}{c}\text { Seasonal } \\
\text { populatio } \\
\text { n }\end{array}$ & $\begin{array}{c}\text { Beach impact } \\
\text { factor } \\
\text { (people/km } \\
\text { of beach) }\end{array}$ \\
\hline AGATHONISI & 0,25 & 158 & - & 34 & 34 & 192 & 768 \\
\hline ARKI & - & 54 & & 45 & 45 & 110 & \\
\hline ASTYPALAIA & 3 & 1.238 & 270 & 1.073 & 1343 & 2.581 & 860,33 \\
\hline $\begin{array}{l}\text { FARMAKONIS } \\
\text { I }\end{array}$ & - & 54 & - & 0 & - & & - \\
\hline HALKI & 0,6 & 313 & 89 & 192 & 281 & 594 & 990 \\
\hline LEROS & 10 & 8.133 & 1.149 & 846 & 1.995 & 10.128 & 1012.8 \\
\hline LIPSI & 0,8 & 600 & 75 & 234 & 309 & 909 & 1136,25 \\
\hline KALYMNOS & 8 & 16.441 & 1918 & 1.216 & 3.134 & 19.575 & 2,68 \\
\hline KARPATHOS & 22 & 5.908 & 4.547 & 1.323 & 5.870 & 11.778 & 535,3 \\
\hline KASOS & 0,6 & 990 & 27 & 60 & 87 & 1.077 & 1795 \\
\hline KOS ${ }^{10}$ & 38.9 & 30.947 & 38.947 & 10.436 & 49.283 & 80.230 & 2,18 \\
\hline MEGISTI & 0,3 & 430 & 73 & 200 & 273 & 703 & 234,33 \\
\hline NISYROS & 5 & 948 & 233 & 150 & 383 & 1.331 & 266,2 \\
\hline PATMOS & 7 & 2990 & 1826 & 1.091 & 2917 & 5.907 & 843.86 \\
\hline PSERIMOS & 4 & 130 & - & 24 & 24 & 154 & 38,5 \\
\hline RHODES [11] & 151 & 117.007 & 73.420 & 15.378 & 88.798 & 205.805 & 2,8 \\
\hline SYMI & 4 & 2.606 & 481 & 569 & 1.050 & 3.656 & 914 \\
\hline TELENDOS & 2 & 54 & 39 & 56 & 95 & 149 & 74,5 \\
\hline TILOS & 5 & 533 & 234 & 419 & 34 & 567 & 113,4 \\
\hline
\end{tabular}

\section{Environmental indicators}

The Psalidi wetlands at Kos and south of Rhodes are considered as the most environmentally sensitive region of the Dodecanese.

\subsection{Beach impact factor}

With this indicator we analyse the pressures facing the coastal environment, as they describe the concentration of people visiting and using the facilities of the coastal area, and especially beaches. 
Rhodes (2.68 persons per metre of beach) and Kos (6.5) do not face the same pressure on their coastal regions as Lipsi (1136.25) and Leros (1012.8). Rhodes and Kos seem to be the islands with the highest number of beaches with Blue Flag certification (10 in Kos and 31 in Rhodes), indicating that serious attempts have been made to protect the environment and possibly increase competitiveness in the tourist services offered. All the other islands do not have any beaches with Blue Flag certification, a result that agrees well with other indicators that they have slow tourist development.

\subsection{Natural environment}

In the Dodecanese there are only two established national parks; one is in Tilos and the other is in Kos. To conclude, we also have fourteen environmentally protected areas, which belong to the "Natura" network. These environmentally protected areas, based on the "Natura" program, do not, as yet, have a management scheme and are not governed by a specific establishment or organization. Two of these areas are in Rhodes and one is in Kos [12]. The Natura area in Kos island houses an important bird area of Greece, the Psalidi wetland area. This wetland area is under threat as it is situated in the suburbs of the town of Kos, which is a main tourist area. The park of Tilos has different species of eagles. Many different migratory birds visit Psalidi in Kos and Tilos island within the year.

The regulations that comprise the management options adopted have been developed and implemented by the Ministry of Environment. In Rhodes, one of the protected areas is the well-known area called the "Butterfly valley" which is managed by the local municipality. Rhodian deer and little ponies from the Archagelos are species of special interest to the island of Rhodes and many efforts are underway to ensure that both survive excessive human intervention. The indicators presented above indicate the number of threatened species in proportion to the total number of native species (Table 10) [13].

\subsection{Garbage and waste management}

Urban waste management (solid and liquid) on all the islands is characterized by the lack of efficiency. Only the large urban centers fulfill the basic requirements of modern waste management installations. It is interesting to note that other smaller settlements do not even have a complete urban waste collection network.

\section{Conclusions}

In this paper we present selected carrying capacity assessment indicators for Dodecanese Archipelago islands that differ in their tourist development, as well as draw some conclusions as to how these indicators can assist in developing sustainable tourist development policies, in island settings. 
Table 10: Protected areas (Natura network) in the Dodecanese related with protected local fauna.

\begin{tabular}{|c|c|c|c|c|c|c|c|c|c|c|}
\hline SITE_NAME & $\begin{array}{r}\text { AREA } \\
\text { (ha) }\end{array}$ & $\begin{array}{l}\text { Manage- } \\
\text { ment } \\
\text { body of } \\
\text { Protected } \\
\text { Area }\end{array}$ & 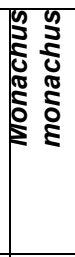 & 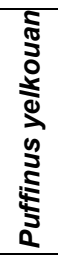 & 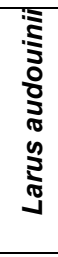 & 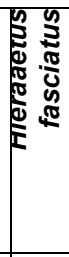 & 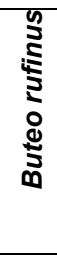 & 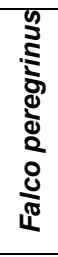 & 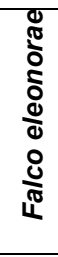 & 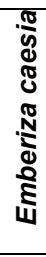 \\
\hline $\begin{array}{ll}\text { KASŌS } & \text { AND } \\
\text { ISLATS } & \end{array}$ & 13452,39 & & $\mathrm{v}$ & & & & & & & \\
\hline $\begin{array}{l}\text { CENTRAL } \\
\text { KARPATHOS AND } \\
\text { ISLETS }\end{array}$ & 9321,90 & $\begin{array}{l}\text { National } \\
\text { Level }\end{array}$ & $\mathrm{v}$ & & $\mathrm{v}$ & $\mathrm{v}$ & & & $\mathrm{v}$ & \\
\hline $\begin{array}{l}\text { NORTH } \\
\text { KARPATHOS }\end{array}$ & 11297,96 & $\begin{array}{l}\text { National } \\
\text { Level }\end{array}$ & $\mathrm{v}$ & & $\mathrm{v}$ & $\mathrm{v}$ & & & $\mathrm{v}$ & \\
\hline $\begin{array}{l}\text { KASTELLORIZO, } \\
\text { RO, STRONGYLI }\end{array}$ & 1769,68 & & & & & & & & & \\
\hline $\begin{array}{l}\text { RODOS: } \\
\text { AKRAMYTIS, } \\
\text { ARMENISTIS, } \\
\text { ATTAVYROS }\end{array}$ & 27514,59 & & $\mathrm{v}$ & & & & & & & \\
\hline $\begin{array}{l}\text { RODOS: } \\
\text { PROFITIS ILIAS - } \\
\text { EPTA PIGES - } \\
\text { PETALOUDES }\end{array}$ & 11184,40 & & & & & & & & & \\
\hline $\begin{array}{l}\text { NOTIA NISYROS } \\
\text { KAI STRONGYLI }\end{array}$ & 4055,74 & & $\mathrm{v}$ & & & & & & $\mathrm{v}$ & $\mathrm{v}$ \\
\hline $\begin{array}{l}\text { KOS: AKROTIRIO } \\
\text { LOUROS - LIMNI } \\
\text { PSALIDI - OROS } \\
\text { DIKAIOS - ALYKI- } \\
\text { PARAKTIA } \\
\text { THALASSIA ZONI }\end{array}$ & 10138,24 & & & & & & & & & \\
\hline $\begin{array}{l}\text { EAST } \\
\text { ASTYPALAIA END } \\
\text { ISLETS }\end{array}$ & 7027,21 & & $\mathrm{v}$ & & & & & & & \\
\hline $\begin{array}{l}\text { ARKOI, LIPSOI, } \\
\text { AGATHONISI AND } \\
\text { ISLETS }\end{array}$ & 12407,03 & & $\mathrm{v}$ & & & & & & & \\
\hline $\begin{array}{l}\text { SOYTH AEGEAN } \\
\text { ISLETS }\end{array}$ & 4568,46 & & & & & & & & & \\
\hline PATMOS ISLETS & 62,00 & & & & & & & & $\mathrm{v}$ & \\
\hline $\begin{array}{l}\text { AGATHONISI, } \\
\text { AND ISLETS }\end{array}$ & 1419,00 & & & $\mathrm{v}$ & $\mathrm{v}$ & & $\mathrm{v}$ & & $\mathrm{v}$ & \\
\hline LIPSI ANS ISLETS & 876,00 & & & $\mathrm{v}$ & $\mathrm{v}$ & & $\mathrm{v}$ & & $\mathrm{v}$ & \\
\hline ARKI AND ISLETS & 502,00 & & & $\mathrm{v}$ & $\mathrm{v}$ & & $\mathrm{v}$ & & $\mathrm{v}$ & \\
\hline LEROS ISLETS & 62,00 & & & & $\mathrm{v}$ & & & $\mathrm{v}$ & $\mathrm{v}$ & \\
\hline $\begin{array}{ll}\text { KALYMNOS } & \\
\text { ISLETS } & \text { AND } \\
\text { TELENDOS } & \\
\end{array}$ & 528,00 & & & & & & $\mathrm{v}$ & $\mathrm{v}$ & $\mathrm{v}$ & \\
\hline $\begin{array}{lr}\text { KINAROS } & \text { KAI } \\
\text { LEVITHA } & \text { KAI } \\
\text { NISIDES } & \text { LIADA, } \\
\text { PLAKA, GLAROS, } \\
\text { MAVRIA }\end{array}$ & 1457,00 & & & & & & & & & \\
\hline $\begin{array}{l}\text { EAST } \\
\text { ASTYPALAIA AND } \\
\text { ISLETS }\end{array}$ & 1459,00 & & & & & & & & $\mathrm{v}$ & \\
\hline
\end{tabular}


Table 11: Urban waste and garbage management in the Dodecanese islands.

\begin{tabular}{|c|c|c|c|c|}
\hline \multicolumn{5}{|c|}{ URBAN WASTE AND GARBAGE MANAGEMENT } \\
\hline & Inhabitants & $\begin{array}{l}\text { Urban waste treatment } \\
\text { plant }\end{array}$ & $\begin{array}{l}\text { Percentage of } \\
\text { waste treated }\end{array}$ & Garbage management \\
\hline AGATHONISI & 158 & NO & 0 & Place of sanitary burial \\
\hline ARKI & 54 & NO & 0 & $?$ \\
\hline ASTYPALAIA & 1.238 & NO & 0 & Scrap heap \\
\hline FARMAKONISI & 54 & NO & 0 & $?$ \\
\hline HALKI & 313 & NO & 0 & Dump place \\
\hline LEROS & 8.133 & 1 & 0 & Dump place \\
\hline LIPSI & 600 & 1 & $100 \%$ & Place of sanitary burial \\
\hline KALYMNOS & 16.441 & $\mathrm{NO}$ & 0 & Dump place \\
\hline KARPATHOS & 5.908 & $\mathrm{NO}$ & 0 & Dump place \\
\hline KASOS & 990 & $\mathrm{NO}$ & 0 & Scrap heap \\
\hline KOS & 30.947 & 1 & $72 \%$ & Place of sanitary burial \\
\hline MEGISTI & 430 & $\mathrm{NO}$ & 0 & Dump place \\
\hline NISYROS & 948 & NO & 0 & Dump place \\
\hline PATMOS & 2990 & 1 & 0 & Dump place \\
\hline PSERIMOS & 130 & $\mathrm{NO}$ & 0 & Dump place \\
\hline RHODES & 117.007 & 5 & $70 \%$ & Place of sanitary burial \\
\hline SYMI & 2.606 & 2 & $25 \%$ & Dump place \\
\hline TELENDOS & 54 & NO & 0 & Dump place \\
\hline TILOS & 533 & $\mathrm{NO}$ & 0 & Place of sanitary burial \\
\hline
\end{tabular}

- The data, presented in the form of tourist infrastructure indicators, highlights the fact that the islands of Kos 169,82 (beds/ $\left.\mathrm{km}^{2}\right)$, Patmos $\left(84.55 \mathrm{beds} / \mathrm{km}^{2}\right)$ and Rhodes $\left(63,51\right.$ beds $\left./ \mathrm{km}^{2}\right)$ have higher tourist concentrations in terms of accommodation. Comparing these three islands to other municipalities, such as most of the Dodecanese archipelago islands, we conclude that the former ones could already be saturated, and have no real capacity for further development in accommodating a greater number of visitors except some municipalities at south Rhodes and west Kos; taking into account other indicators the conclusion is reached that these saturated islands can progress towards developing quality and alternative tourist services. Areas that have not been developed, should not necessarily develop along the same lines as the major tourist attraction areas, but should, at this stage of their development, plan ahead in order that planning and policy development and implementation lead to a truly competitive and environmentally sound business [14].

- Hotel occupancy indicators for Kos and Rhodes, showing 50\% during low season and $100 \%$ in the peak periods, combined with the fact that the tourist season on the other islands is mainly during the months of August and July, as hotel occupancy in October in Karpathos is $10 \%$ of the occupancy in August, lead us to conclude that the tourist industry should aim at extending the tourist 
season to include more months, and probably visitors with varied interests and expectations of the beautiful islands [15].

- Kos, through local tourism organizations, has achieved a better balance between high and low season tourist figures compared with tourism in Rhodes and all the other Dodecanese and seen the need for policies and measures aimed at alternative tourist attractions, thus achieving a better quality and extended tourist season [16]. In Karpathos October arrivals (3.234 passengers) are only $20 \%$ of the August arrivals (15.130).

- Environmental indictors indicate that the transformation from a low quality, high numbers tourist trade, to an alternative high quality one will not be easy, since waste management systems are insufficient in dealing with urban and solid waste. It is well known that such inadequacies have serious environmental consequences, and hinder any attempts towards developing a tourist industry based on quality. Urban waste treatment plants operate only at Rhodes, Kos, Lipsi and Symi.

- Calculated coastline impact indicators indicate that the island of Kalymnos (with a total of $8 \mathrm{~km}$ of beach), Kos $38.9 \mathrm{Km}$ of beach and Rhodes $151 \mathrm{Km}$ of beach, does not face the same pressure on its coastal regions (data in people $/ \mathrm{km}$ of beach) as Lipsi 1.136,25, Leros 1.012, Astypalaia 860,33, Simi 914, Halki 990 and Patmos 843.86

- The Dodecanese has 14 environmentally protected areas. The increasing public interest in nature and landscape preservation is, today, considered a major positive factor in the tourist development process. It is true that the growing influx of visitors can exert strong pressures on fragile ecosystems [17]. Environmentally sensitive areas should have an effective management scheme:[18] and be run under a modern and highly sophisticated regime.

\section{Acknowledgements}

We would like to thank for their help and collaboration: Dimitra Tselou, economist, University of Piraeus, Spyros Gavanozis Hellenic Civil Aviation Authority, Loucas Mastis, Chief Editor "Rodiaki" newspaper, Mr Petsis, Department of Tourism, Periphery of South Aegean, Rhodes and Paraschos, Vasiliki, Maria and Matia Zouglas, Rhodes and Nikos Kadarzis, Kos.

\section{References}

[1] UNEP/MAP/PAP, 1997

[2] Coccosis H and Mexa A, 'The challenge of Tourism Carrying Capacity Assesment', Ashgate 2004

[3] Fernando J Garrigós Simón, Y. Narangajavana, and D. Palacios-Marqués. 'Carrying capacity in the tourism industry: a case study of Hengistbury Head' 
[4] Jurincic I 'Carrying capacity assessment of Slovene Istria for tourism', $2^{\text {nd }}$ International Conference on sustainable planning and development Bologna 2005, Wessex Institute of Technology

[5] Zannou V, 'Guide of Socio-Economic Studies for the Integrated Management of the Water Environment' 1999

[6] Direction of Tourism, Periphery of South Aegean, Rhodes

[7] Mr Petsis, 'Department of Tourism, Periphery of South Aegean, Rhodes'

[8] Logothetis M. Dodecanese economy 1988-89, Athens 1990

[9] Hellenic Civil Aviation Authority, Air traffic statistics for 2003

[10] Prokopiou DG 'A study of environmental impact assessment in Kos and Rhodes coasts' Third Conference in Coastal Management, National Technical University of Athens, Athens 2005(in Greek)

[11] Prokopiou DG - Tselentis BS ' Environmental Impacts of Development in Rhodes' International Conference of sustainable planning and development Skiathos 2003, Wessex Institute of Technology

[12] Hellenic Ornithological Society, www.ornithologiki.gr

[13] Indicators for the sustainable development in the Mediterranean region, Blue Plan - PNUE 2000

[14] 'Rodiaki' newspaper 2006-02-12

[15] Prokopiou DG and Tselentis BS 'Regional development and the islands of Kos and Rhodes - a study of sustainable financial opportunities' 2nd Conference on sustainable planning and development Bologna 2005, Wessex Institute of Technology

[16] Prokopiou DG, MBA Dissertation: 'Regional Investment Study for Kos and Rhodes islands', University of Piraeus, 2005(in Greek)

[17] Papayanis T, 'Tourism carrying capacity in areas of ecological importance'

[18] Prokopiou DG and Tselentis BS 'Proposals for sustainable development and Environmental protection for the island of Rhodes', Rhodes 2003 (in Greek) 